\title{
RURAL VERSES URBEN MARKETING AND CHANGE IN CONSUMER BEHAVIOUR IN RURAL MARKETING
}

\author{
K.B. Lahari, \\ Assiastant Professor, \\ Department of Business Management, \\ SDGS college,Hindupur 515201 \\ laharivishala@gmail.com
}

\begin{abstract}
The main objective of the study is to make out the differences of rural and urban markets and changing consumer behavior in rural markets. It is very difficult to understand and make changes in the consumer behavior in rural markets which is influenced by several factors like social environment economic factors ,place of purchase and family.
\end{abstract}

Introduction : Consumer behavior refers to the buying behavior of final consumersindividuals and households who buys good and services for personal consumption. About $70 \%$ of Indians lives in rural area. Rural people react differently to different products and their sizes based on region. Factors affecting buying behavior in rural markets are geographical influence, family, economic factors, place of purchase, social practices, decision making by female.

Rural marketing integrates the process of pricing, promoting, distributing rural specific products satisfying consumer demand by providing exchange between rural and urban markets. Rural marketing creates relationship by inclusive growth of product or service. In rural marketing Buyer looks for quality products that offer value for money. Demographic \& geographic segmentation can be the base to divide the market. If we can create a brand name then we can capture the market with enough profitability. Primarily appropriate technologies can be used for rural innovation.

Urban marketing is fully integrated which presents comprehensive level of services, offering pre development guidance, branding, marketing and most effective sales agent in parallel areas. In urban marketing we can create relationship by offering integrated innovation in product or service. Buyer looks for style, quality \&novelty. Internet, TV channels, mobile can be used for research and High technology can be used to create product.

Consumers in India have become more conscious by looking at the options, engaging over internet and understanding usefulness of products. Consumers are more informed in buying products after their own research or by company promotions. There are several challenges in rural and urban marketing which are Traditional life style, Transportation, literacy, promotion and marketing communication, low demand, high degree of competition and large expenses. The main difference between rural and urban marketing are

Population, Channels of distribution, Channels of communication, Population

Out of total population $73 \%$ of Indian population lives in rural areas and $27 \%$ lives in urban. 


\section{Channels of distribution}

Distribution channels include wholesalers, e-commerce websites, catalog sales, consultants, a direct sales force who sell over the phone, in person or both, dealers, home shopping networks and retailers. The distribution channel or channels selected can dictate what the rest of the marketing strategy would be, as they influence the buyer directly. Advertising and other marketing methods would then appeal to the buyer's demographic. Small businesses with limited resources or financial support must perform a careful market analysis to determine which distribution channel is best suited for their customers.

Channels of communication: Channels of communication in rural markets can be Advertising, Sales promotion, Direct Marketing, Public Relation and publicity, News papers, Local magazines, Leaflets, Hoarding etc.,

Change in Consumer behavior in rural markets can be done by providing

Quality of products

Easy availability of credits (EMI, Loans)

Good Transportation Facilities

Price value equation

Experimenting with new products/impulsive buying

Brand Awareness

Quality of products

If a product fulfils the customer's expectations, the customer will be pleased and consider that the product is of acceptable or even high quality. If his or her expectations are not fulfilled, the customer will consider that the product is of low quality. This means that the quality of a product may be defined as "its ability to fulfill the customer's needs and expectations". Hence products with good quality should be provided in rural areas in order to give them satisfaction for the money which they have spent in purchasing it.

Easy availability of credits: Standard of living in rural areas in comparatively low when compared to urban which has direct impact on consumer behavior of people in rural areas. Consumers can be provided a credit system in purchasing the product. The best way is to implement EMI system in rural where the pay can be done monthly to one particular person who acts as an in charge for that area.

Good Transportation Facilities: Even though the quality of products are been provided to rural areas lack of proper transportation facilities huge amount of damage is happening to the products. Hence people are not ready to buy the damaged goods which leads to the dissatisfaction of consumers. One of the main reasons is uneven roads. Since villages do not have proper facilities and amenities even Companies do not wish to establish factories in rural areas, as they are unable to attract professionals and technicians to work there.

Price value of money: Price value of money depends on elements of marketing mix product, price, place, promotion, people, process and physical evidence. If customers don't think they are getting value for money, then there is no pricing power-companies can't lift prices to maintain profitability without losing many customers. However, if customers believe they are getting value for 
money, they will remain loyal despite price increases in rural markets. Value can be separated into seven components such as service, response, variety, quality, guarantee, and price. Consumers in India have now become more value conscious. They are demanding higher services and value for their money. Be it electronics, automobile, merchandises or any other items, they are now looking at high value for product that is able to meet their expectations. With the ever increasing purchasing power, Indian consumers are now driven by rationale mindset.

Brand Awareness: For a rural customer, a branded product is bigger investment they expect value for money. In my view brand awareness in rural marketing can be done through Word of Mouth, Advice of retailer/distributor, Hoardings and Roadshows, TV and Radio Ads. Depending on product and consumer demographics.

Hence rural verses urban marketing and changes in consumer behavior in rural markets. 